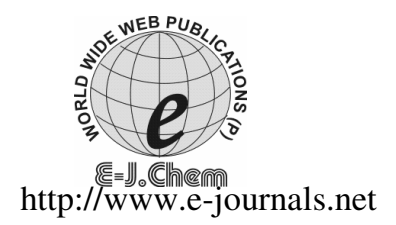

ISSN: 0973-4945; CODEN ECJHAO

E-Journal of Chemistry 2010, 7(1), 260-264

\title{
Simultaneous RP HPLC Determination of Aceclofenac, Paracetamol and Tizanidine in Pharmaceutical Preparations
}

\author{
V. V. VAIDYA* G. R. SINGH, \\ M. P. CHOUKEKAR ${ }^{\S}$ and M. B. KEKARE ${ }^{\S}$ \\ Department of Chemistry, \\ S.P.Mandali's Ramnarain Ruia College, Matunga, Mumbai-400019, India. \\ ${ }^{\S}$ Department of Chemistry. \\ Kirti M. Dongursee College, Dadar, Mumbai-400028, India. \\ mpc26@rediffmail.com
}

Received 10 February 2009; Accepted 5 April 2009

\begin{abstract}
A simple, fast and precise reverse phase high performance liquid chromatographic method is developed for the simultaneous determination of aceclofenac, paracetamol and tizanidine. Chromatographic separation of the three drugs were performed on a hypersil $\mathrm{C}_{18}$ column $(250 \mathrm{~mm} \times 4.6 \mathrm{~mm}, 5 \mu \mathrm{m})$ as stationary phase with a mobile phase comprising of mix phosphate buffer pH 7.0: acetonitrile $(40: 60 \mathrm{v} / \mathrm{v})$, at a flow rate of $0.7 \mathrm{~mL} \mathrm{~min}^{-1}$ and UV detection at $230 \mathrm{~nm}$. The proposed method was validated for linearity, accuracy, precision, LOD, LOQ. Linearity, accuracy and precision were found to be acceptable over the ranges of $100-300 \mu \mathrm{g} \mathrm{mL}{ }^{-1}$ for aceclofenac, 500-1500 $\mu \mathrm{g} \mathrm{mL} \mathrm{m}^{-1}$ for paracetamol and 2-6 $\mu \mathrm{g} \mathrm{mL}^{-1}$ for tizanidine $\mathrm{HCl}$ equivalent to tizanidine. It can be conveniently adopted for routine quality control analysis.
\end{abstract}

Keywords: Validation, Pharmaceutical preparations, Aceclofenac, Paracetamol, Tizanidine HCl.

\section{Introduction}

Aceclofenac $\left\{\left[2-\left(2^{\prime}, 6^{\prime}\right.\right.\right.$-dichlorophenyl) amino] phenyl acetoxyacetic acid $\}$ is a new phenyl acetic acid derivative with potent analgesic and anti-inflammatory properties and improved gastric tolerance ${ }^{1}$. Paracetamol is chemically 4-hydroxy acetanilide, a centrally and peripherally acting analgesic and antipyretic agent ${ }^{2}$. Tizanidine $\mathrm{HCl}$ (TIZ) is 5-chloro-4-[2imidazolin-2-yl-amino]-2,1,3-benzothiadiazole. It is used as skeletal muscle relaxant ${ }^{3}$. The structures of these three drugs are shown in Figure 1. One such combination contains $100 \mathrm{mg}$ of aceclofenac, $500 \mathrm{mg}$ of paracetamol and $2 \mathrm{mg}$ of tizanidine $\mathrm{HCl}$ equivalent to tizanidine. 
It is widely used as anti-inflammatory analgesic. The literature revealed that, no method was available for simultaneous determination of these three drugs in such pharmaceutical preparations by HPLC. Therefore an HPLC method was developed for determination of aceclofenac, paracetamol and tizanidine from their combined dosage form ${ }^{6-11}$. The method described is simple, fast, precise and accurate for simultaneous determination of aceclofenac, paracetamol and tizanidine from pharmaceutical preparation.<smiles>O=C(O)COC(=O)Cc1ccccc1Nc1c(Cl)cccc1Cl</smiles>

Figure 1. Structures of aceclofenac.<smiles>CC(C(Cl)Cl)N1CCN=C1Nc1c(Cl)ccc2nsnc12</smiles>

Figure 2. Structures of tizanidine hydrochloride.<smiles>CCCCCCCCONC(C)=O</smiles>

Figure 3. Structures of paracetamol.

\section{Chemicals and reagents}

Standards were supplied from J.B. Chemicals \& Pharmaceuticals Ltd., Mumbai, India. Zerodol-MR tablets manufactured by Ipca laboratories, India was procured from the market. Acetonitrile, potassium dihydrogen orthophosphate and sodium dihydrogen orthophosphate were from Qualigens. Double distilled water was employed throughout the work. All dilutions were performed in standard volumetric flasks.

\section{Experimental}

To develop a suitable LC method for the analysis of aceclofenac, paracetamol and tizanidine in their combined dosage form, different mobile phases were tried. The criteria employed for selecting the mobile phase for the analyses of the drugs were cost involve, time required for the analysis, better separation of drugs. Chromatographic separation was preformed with Agilent 1100 series High Performance Liquid Chromatography having HPLC isocratic pump, equipped with auto sampler and a photo-diode array detector. The UV spectra of all the three drugs were scanned on photo diode array detector for selecting the working wavelength. Peak purity of all the three drugs was checked using photo diode array detector. Chromatograms and data were recorded by means of chemstation software. A hypersil $\mathrm{C}_{18}$ column $(250 \mathrm{~mm} \times 4.6 \mathrm{~mm}, 5 \mu \mathrm{m}$ particle) was used for the analysis. The mobile phase comprising of mix phosphate buffer $\mathrm{pH}$ 7.0: acetonitrile in the ratio (40:60) v/v. The system was run at a flow rate of $0.7 \mathrm{~mL} \mathrm{~min}^{-1}, 5 \mu \mathrm{L}$ of sample was injected in the chromatographic system and detection wavelength was set at $230 \mathrm{~nm}$ for simultaneous determination of these three drugs. A typical HPLC chromatogram for simultaneous determination of aceclofenac, paracetamol and tizanidine from pharmaceutical formulation is shown in Figure 4 and Figure 5.

\section{Preparation of standard stock solutions}

The stock solution of aceclofenac $\left(4000 \mu \mathrm{g} \mathrm{mL}^{-1}\right)$ was prepared by dissolving $99.11 \mathrm{mg}$ of aceclofenac $(99.9 \%)$ in water:acetonitrile $(50: 50)$ in a standard $25 \mathrm{~mL}$ volumetric flask (solution A). The stock solution of paracetamol $\left(10000 \mu \mathrm{g} \mathrm{mL} \mathrm{L}^{-1}\right)$ was prepared by dissolving $250.21 \mathrm{mg}$ of paracetamol $(99.8 \%)$ in water:acetonitrile (50:50) in a standard $25 \mathrm{~mL}$ volumetric flask (solution $\mathrm{B}$ ). The stock solution of tizanidine $\mathrm{HCl}$ equivalent to tizanidine (4 $\mu \mathrm{g} \mathrm{mL} \mathrm{g}^{-1}$ ) was prepared by dissolving $11.45 \mathrm{mg}$ of tizanidine $\mathrm{HCl}(99.8 \%)$ in water:acetonitrile (50:50) in a standard $25 \mathrm{~mL}$ volumetric flask (solution $\mathrm{C}$ ). 


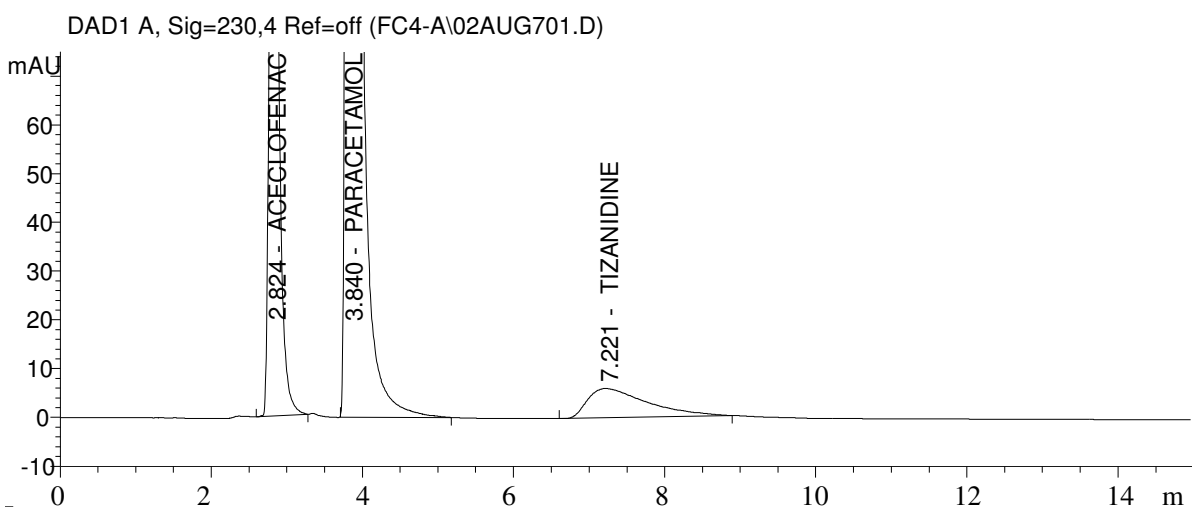

Figure 4. Chromatogram of aceclofenac, paracetamol and tizanidine $\mathrm{HCl}$ in standard preparation. DAD1 A, Sig=230,4 Ref=off (FC4-Al02AUG702.D)

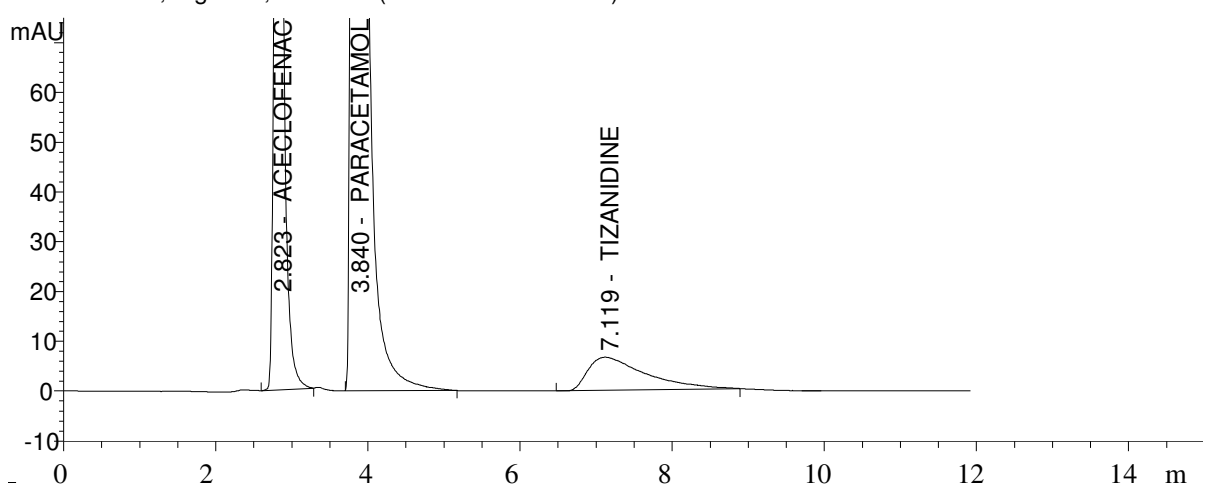

Figure 5. Chromatogram of aceclofenac paracetamol and tizanidine $\mathrm{HCl}$ in sample preparation.

\section{Working standard solution}

Transferred $5.0 \mathrm{~mL}$ of stock solution A, $10.0 \mathrm{~mL}$ of stock solution B and $1.0 \mathrm{~mL}$ of stock solution $\mathrm{C}$ to a $100 \mathrm{~mL}$ volumetric flask and diluted up to the mark with water:acetonitrile (50:50).

\section{Sample preparation}

Twenty tablets were weighed and their average weight was calculated. The tablets were crushed into a homogeneous powder and a quantity equivalent to one tablet was transferred in a $500 \mathrm{~mL}$ volumetric flask, dissolved in water:acetonitrile (50:50), and filtered through Whatman no. 41 filter paper.

\section{Results and Discussion}

System suitability

System suitability tests are used to verify that the reproducibility of the equipment is adequate for the analysis to be carried out ${ }^{4-5}$. System suitability tests were performed as per the USP 31 to confirm the suitability and reproducibility of the system. The test was carried out by injecting 5- $\mu \mathrm{L}$ standard solutions of aceclofenac, paracetamol and tizanidine of strengths 200 $\mu \mathrm{g} \mathrm{mL}^{-1}, 1000 \mu \mathrm{g} \mathrm{mL}^{-1}$ and $4 \mu \mathrm{g} \mathrm{mL}^{-1}$ respectively. This was repeated five times. The RSD values of aceclofenac, paracetamol and tizanidine were $0.09,0.52$ and 0.77 respectively. The RSD values were found to be satisfactory and meeting the requirements of USP 31 . Theoretical plates, resolution, tailing factor were determined and are presented in Table 1 . 
Table 1. Result of system suitability

\begin{tabular}{cccc}
\hline Parameters & Aceclofenac & Paracetamol & Tizanidine \\
\hline Resolution & - & 5.490 & 4.209 \\
Tailing factor & 1.359 & 1.637 & 2.480 \\
Theoretical plates & 3291 & 7841 & 1129 \\
\hline
\end{tabular}

\section{Linearity}

Linearity was evaluated by analysis of working standard solutions of aceclofenac, paracetamol and tizanidine of seven different concentrations ${ }^{4-5}$. The range of linearity was from 100-300 $\mu \mathrm{g} \mathrm{mL} \mathrm{L}^{-1}$ for aceclofenac, $500-1500 \mu \mathrm{g} \mathrm{mL}^{-1}$ for paracetamol and 2-6 $\mu \mathrm{g} \mathrm{mL}^{-1}$ for tizanidine $\mathrm{HCl}$ equivalent to tizanidine. The peak area and concentration of each drug was subjected to regression analysis to calculate the calibration equations and correlation coefficients. The regression data obtained are represented in Table 2 . The result shows that within the concentration range mentioned above, there was an excellent correlation between peak area ratio and concentration of each drug.

Table 2. Results of linearity.

\begin{tabular}{cccc}
\hline Analyte & Slope (mean) & Intercept (mean) & $\begin{array}{c}\text { Correlation coefficient } \\
\left(\mathrm{r}^{2}\right)(\mathrm{n}=7)\end{array}$ \\
\hline Aceclofenac & 14.13 & 0.86 & 0.9998 \\
Paracetamol & 89.30 & -0.63 & 0.9999 \\
Tizanidine & 3.20 & 1.66 & 0.9998 \\
\hline
\end{tabular}

\section{Limit of detection and limits of quantitation}

The limit of detection (LOD) and limit of quantitation (LOQ) were established at signal-tonoise ratio of 3:1 and 10:1 respectively ${ }^{4-5}$. The LOD and LOQ of aceclofenac, paracetamol and tizanidine were experimentally determined by six injections of each drug. The LOD of aceclofenac, paracetamol and tizanidine were found to be $0.3 \mu \mathrm{g} \mathrm{mL}^{-1}, 0.3 \mu \mathrm{g} \mathrm{mL}^{-1}$ and $0.03 \mu \mathrm{g} \mathrm{mL}^{-1}$ respectively. The $\mathrm{LOQ}$ of aceclofenac, paracetamol and tizanidine were found to be $1.0 \mu \mathrm{g} \mathrm{mL}^{-1}, 1.0 \mu \mathrm{g} \mathrm{mL}^{-1}$ and $0.1 \mu \mathrm{g} \mathrm{mL}^{-1}$ respectively.

\section{Precision}

Repeatability was studied by carrying out system precision. System precision was determined from results for six replicate injections of the mixed standard solutions ${ }^{4-5}$. The relative standard deviations were less than $2 \%$ for the two drugs. Method precision was determined from results from ten independent determinations at $100 \%$ of the test concentrations of aceclofenac, paracetamol and tizanidine in the product. The \%RSD were $0.31,0.09$ and 0.16 respectively (Table 3 ).

Table 3. Results of assay experiment

\begin{tabular}{cccc}
\hline & Aceclofenac & Paracetamol & $\begin{array}{c}\text { Tizanidine } \mathrm{HCl} \text { equivalent to } \\
\text { Tizanidine }\end{array}$ \\
\hline Drug found in mg/tablet(mean) & 99.86 & 501.2 & 1.99 \\
Mean \% & 99.91 & 100.21 & 100.63 \\
RSD & 0.31 & 0.09 & 0.16 \\
\hline
\end{tabular}

\section{Accuracy}

To study accuracy of the method, recovery experiment was carried out by applying the standard addition method. A known quantity of each drug substance corresponding to $100 \%, 110 \%, 120 \%$ and $130 \%$ of the label claim of each drug was added, to determine if there are positive or negative interferences from excipients present in the formulation ${ }^{4-5}$. Each set of addition was repeated 
three times .The accuracy was expressed as the percentage of analytes recovered by the assay. Table 4 lists the recoveries of the drugs from a series of spiked concentrations. The results indicate the method is highly accurate for simultaneous determination of the three drugs.

Table 4. Accuracy of the method.

\begin{tabular}{ccccccc}
\hline Analyte & $\begin{array}{c}\text { Initial } \\
\text { conc., mg }\end{array}$ & $\begin{array}{c}\text { Conc. } \\
\text { added, mg }\end{array}$ & $\begin{array}{c}\text { Total } \\
\text { conc., mg }\end{array}$ & $\begin{array}{c}\text { Conc. } \\
\text { found, mg }\end{array}$ & $\begin{array}{c}\text { RSD, \% } \\
\mathrm{n}=3\end{array}$ & $\begin{array}{c}\text { Recovery, } \\
\%\end{array}$ \\
\hline \multirow{3}{*}{ Aceclofenac } & 100 & 0 & 100 & 99.86 & 0.11 & 99.86 \\
& 100 & 10 & 110 & 109.94 & 0.16 & 99.95 \\
& 100 & 20 & 120 & 120.56 & 0.09 & 100.47 \\
& 100 & 30 & 130 & 130.11 & 0.07 & 100.08 \\
Paracetamol & 500 & 0 & 500 & 501.2 & 0.16 & 100.24 \\
& 500 & 50 & 550 & 555.23 & 0.34 & 100.95 \\
Tizanidine HCl & 500 & 100 & 600 & 599.10 & 0.09 & 99.85 \\
equivalent to & 2 & 150 & 650 & 649.94 & 0.23 & 99.99 \\
Tizanidine & 2 & 0 & 2 & 1.99 & 0.14 & 99.50 \\
& 2 & 0.2 & 2.2 & 2.19 & 0.05 & 99.55 \\
\hline
\end{tabular}

\section{Conclusion}

Several mobile phases such as water-methanol, water-acetonitrile in different ratios were tried but good peak shape and good resolution between aceclofenac, paracetamol and tizanidine was observed using the mobile phase mentioned in chromatographic conditions. The method after being completely validated showed satisfactory data for all the method validation parameters. The method was found to be specific. The low values of \%RSD for method precision suggested that the method is precise. Linearity evaluated for the analyte peak showed a good linear response over a wide range of concentration. The linearity, precision, accuracy of the method proves that the method is specific, accurate, easily reproducible and can be used for simultaneous determination of aceclofenac, paracetamol and tizanidine from pharmaceutical preparations.

\section{References}

1. European Pharmacopea 6.0. 2, 1093-1095.

2. USP-31, NF 26, 2, 1268-1269.

3. USP-31, NF 26, 3, 3415-3416.

4. Snyder LR, Kirland J J and Glajch J L, Practical HPLC method development, $2^{\text {nd }}$ Ed., John Wiley and Sons, Inc., U.S.A, 1997.

5. ICH, Validation of analytical procedures: methodology, ICH harmonized tripartite guidelines, 1997.

6. El-Saharty Y S, Refaat M and El-Khateeb S Z, Drug Dev Ind Pharm., 2002, 28, 571.

7. Zawilla N H, Mohammad M A, El-Kousy N M and El-Moghazy Aly S M, J Pharm Biomed Anal., 2002, 27, 243.

8. Hinz B, Auge D, Rau T, Rietbrock S, Brune K and Werner U, Biomed Chromatogr., 2003, 17, 268.

9. Subramanian G, Musmade P, Agarwal S and Udupa N, Indian J Pharm Sci., 2004, 66(5), 694-696.

10. Momin M Y, Yeole P G, Puranik M P, Wadher S J, Indian J Pharm Sci., 2006, 68(3), 387.

11. Gopinath R, Rajan S, Meyyanathan S N, Krishnaveni N and Suresh B, Indian J Pharm Sci., 2007, 69(3), 137-140. 


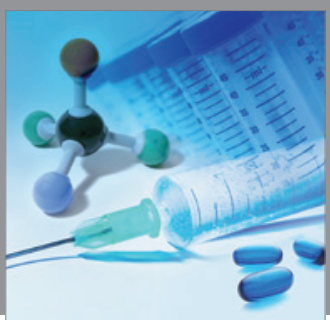

International Journal of

Medicinal Chemistry

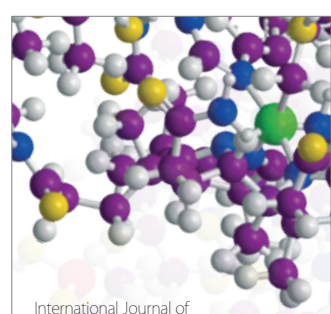

Carbohydrate Chemistry

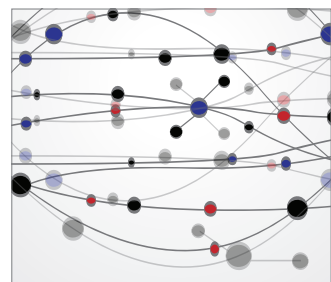

The Scientific World Journal
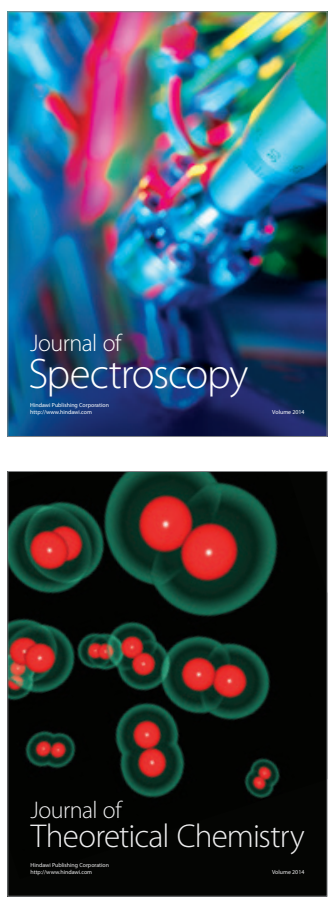
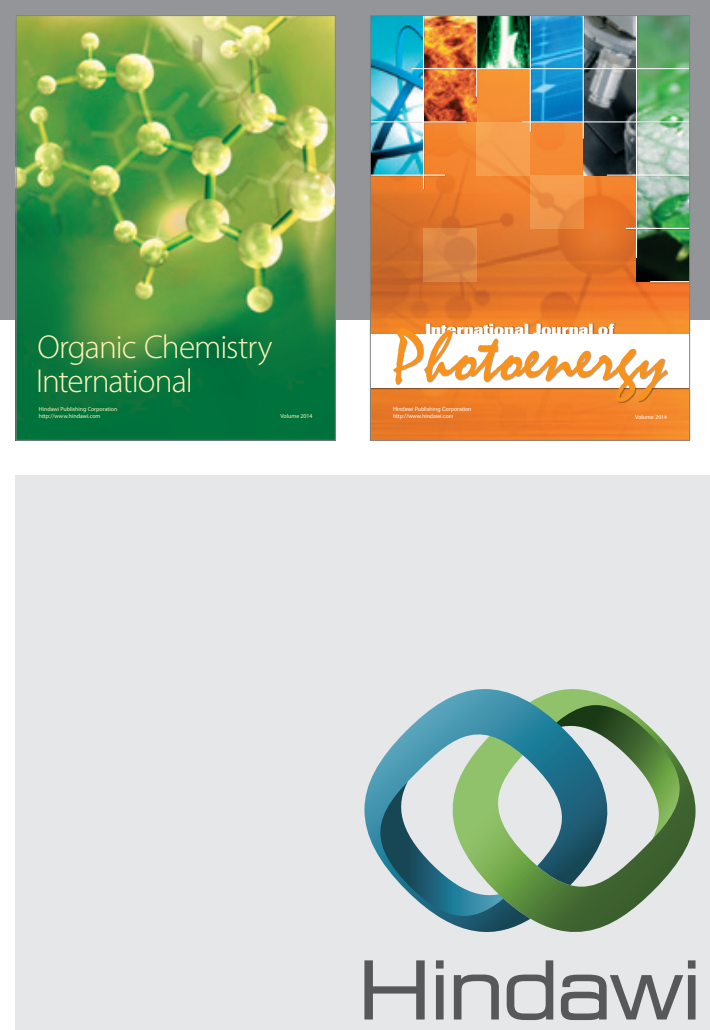

Submit your manuscripts at

http://www.hindawi.com
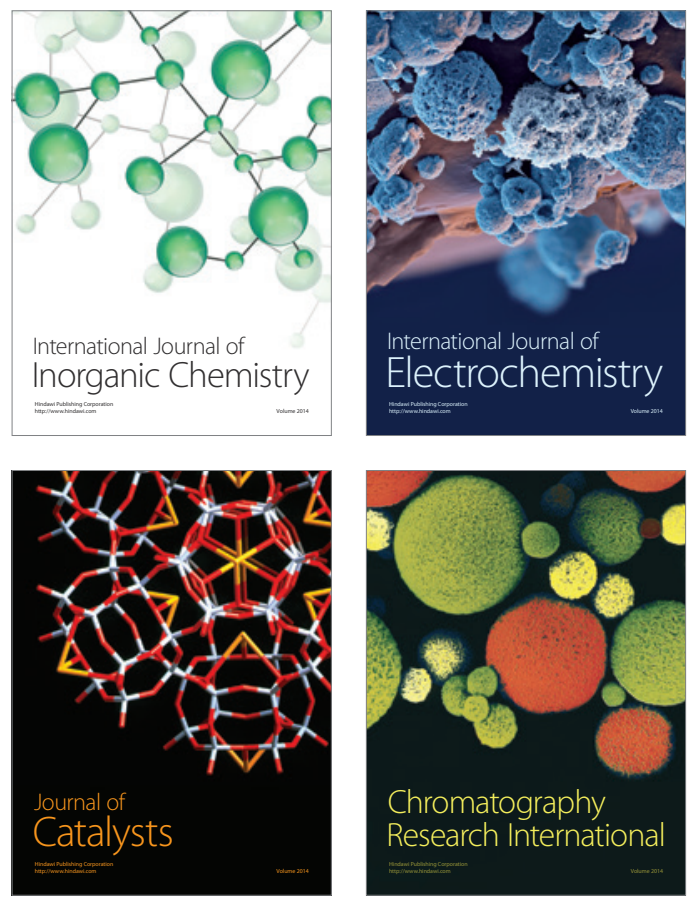
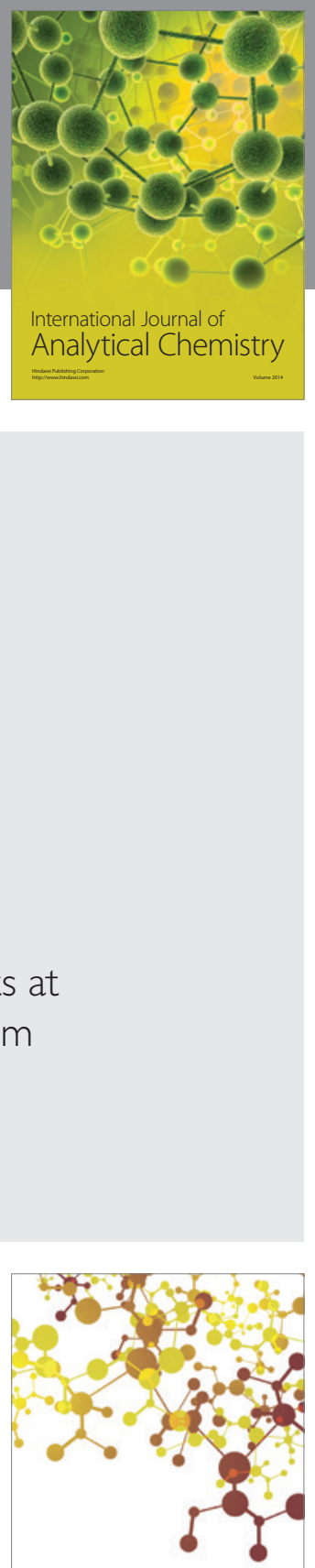

Journal of

Applied Chemistry
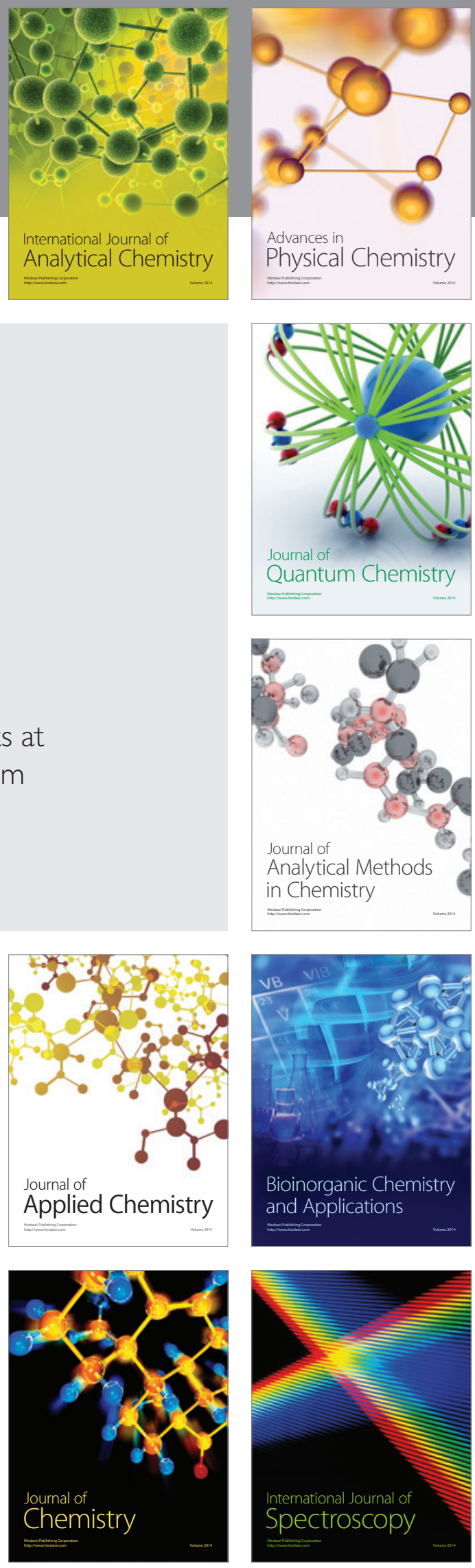